\title{
Hypertriglyceridemia-Induced Acute Pancreatitis
}

\author{
Jin Myung Park \\ Department of Internal Medicine, Kangwon National University Hospital, Kangwon National University School of Medicine, Chuncheon, Korea
}

Hypertriglyceridemia is a well-established cause of acute pancreatitis. The clinical presentation of hypertriglyceridemia-induced acute pancreatitis (HTG-AP) is generally not different from that of acute pancreatitis of any other etiology. There is concern about severity of HTG-AP, but data specifically comparing the severity of HTG-AP with that of acute pancreatitis caused by other etiologies are heterogeneous and scarce. Elevation of serum triglyceride levels to $\geq 1,000 \mathrm{mg} / \mathrm{dL}$ in a patient with acute pancreatitis provides strong support for HTG as the cause. Poorly controlled diabetes, obesity, alcoholism, pregnancy, and personal or family history of hyperlipidemia suggest HTG-AP. Initial supportive treatment of HTG-AP is not quite different from that of acute pancreatitis by other etiologies. In addition, insulin and plasmapheresis were effective in some studies. However, randomized controlled trials are needed to support these treatment methods. Lifestyle modifications and lipid lowering agents are required to prevent recurrences.

Korean J Pancreas Biliary Tract 2017;22(4):158-164

Keywords: Hypertriglyceridemia, Pancreatitis, Insulin, Plasmapheresis
Received Sep. 17, 2017
Revised Oct. 10, 2017
Accepted Oct. 10, 2017

Corresponding author : Jin Myung Park

Department of Internal Medicine, Kangwon National University Hospital, Kangwon National University School of Medicine, 156 Baekryung-ro, Chuncheon 24289, Korea

Tel. +82-33-258-9235 Fax. +82-33-258-2455

E-mail; youreon.park@gmail.com

This is an Open Access article distributed under the terms of the Creative Commons Attribution Non-Commercial License (http:/ creativecommons.org/licenses/by-nc/3.0/) which permits unrestricted non-commercial use, distribution, and reproduction in any medium, provided the original work is properly cited.

Copyright $\odot 2017$ by The Korean Journal of Pancreas and Biliary Tract

\section{서 론}

급성 췌장염은 췌장의 염증성 질환이며 대개 가볍게 지나가 지만 심한 췌장염을 보이는 일부 환자에서는 사망률이 $30 \%$ 에 이른다. ${ }^{1}$ 급성 췌장염의 원인을 밝히는 것은 치료의 근간이 되 며 가장 흔한 원인 두 가지는 음주와 담석으로 알려져 있다. ${ }^{2}$ 그런데 고중성지방혈증(hypertriglyceridemia) 역시 급성 췌장 염의 잘 알려진 원인이다. 최근 발표된 체계적 문헌고찰(systematic review)에서 전체 급성 췌장염의 $9 \%$ 정도가 고중성지
방혈증에 의한 것이고 고중성지방혈증 환자의 약 $14 \%$ 에서 급 성 췌장염이 발생하는 것으로 보고되었다. ${ }^{3}$ 아울러 임신 중 췌 장염에 관한 연구에서는 고중성지방혈증에 의해 유발된 급성 췌장염이 전체 증례의 절반 이상을 차지하는 것으로 나타났 다. ${ }^{4}$ 이처럼 고중성지방혈증에 의한 급성 췌장염(hypertriglyceridemia-induced acute pancreatitis, HTG-AP)이 적지 않게 발 생하고 있으나 아직까지 잘 설계된 대규모 임상연구가 거의 없 고 의사들의 인식도 부족한 상황이다. 본 종설에서는 HTG-AP 의 임상적 특성 및 치료에 관하여 정리해 보고자 한다. 


\section{본 론}

\section{1. 혈중 중성지방 농도와 급성 췌장염}

전통적으로 HTG-AP는 혈중 중성지방 농도가 $1,000 \mathrm{mg} / \mathrm{dL}$ $(11.3 \mathrm{mmol} / \mathrm{L})$ 이상일 때 발생하는 것으로 알려져 있으나 ${ }^{5,6}$ 이 수치가 절대적인 것은 아니며 급성 췌장염을 유발하는 고중성 지방혈증의 역치값도 분명하지는 않다. ${ }^{7}$ 그런데 여러 연구에 따르면 혈중 중성지방 농도가 증가할수록 급성 췌장염의 발생 위험도는 증가한다. Sandhu 등 ${ }^{8}$ 은 고지질혈증으로 12 년간 외 래 진료를 받은 환자군 자료를 바탕으로 혈중 중성지방 농도 가 $20 \mathrm{mmol} / \mathrm{L}(1,771 \mathrm{mg} / \mathrm{dL})$ 를 넘는 경우 $10-20 \mathrm{mmol} / \mathrm{L}(886-$ $1,771 \mathrm{mg} / \mathrm{dL}$ )인 환자군에 비해 급성 췌장염의 병력이 많았다 고 보고하였다( $15.8 \%$ vs. $3.3 \%)$. Linares 등 ${ }^{9}$ 은 혈중 중성지방 농도가 $1,000 \mathrm{mg} / \mathrm{dL}$ 를 넘는 129 명의 코호트를 분석하여 보고 하였다. 이 연구에서 다른 원인에 의한 급성 췌장염을 배제하 였을 때 $20.2 \%$ 의 환자에서 급성 췌장염의 병력이 있었고 혈중 중성지방 농도를 기준으로 세 그룹으로 나누었을 때 급성 췌장 염에 대한 odds ratio (third tertile vs. first tertile)가 4.0으로 나 타났으며 95\% confidence interval (CI) 1.3-12.6으로 유의한 차 이를 보였다. Bessembinders 등 ${ }^{10}$ 은 혈중 중성지방이 한 번이라 도 $1,000 \mathrm{mg} / \mathrm{dL}$ 를 초과하였던 300 명의 입원 및 외래 환자를 대 상으로 한 연구를 발표하였다. 이 연구에 따르면 급성 췌장염 의 병력이 있는 환자 및 급성 췌장염이 확인된 환자가 혈중 중 성지방이 $1,415-2,411 \mathrm{mg} / \mathrm{dL}$ 인 군에서 각각 $8 \%, 4 \%$ 였던 반면 $2,411 \mathrm{mg} / \mathrm{dL}$ 초과인 군에서는 $19 \%, 11 \%$ 로 더 높게 나타났다. 아울러 급성 췌장염 환자의 $2 / 3$ 이상이 혈중 중성지방 2,411 $\mathrm{mg} / \mathrm{dL}$ 초과인 군에서 확인되었다.

\section{2. 병태생리}

현재까지 HTG-AP의 병태생리학적 기전은 불분명하며 동 물실험을 통해 몇 가지 가설이 제시되었다. 가장 유력한 이론 에 의하면 과다한 중성지방은 췌장에서 분비되는 lipase에 의해 가수분해되어 다량의 유리지방산(free fatty acid)을 생성하게 된다. 과다 생성된 유리지방산은 알부민의 결합능력을 초과하 여 서로 뭉치게 되고 세정제(detergent)의 성질을 갖는 미셀구 조(micellar structure)를 이루어 췌장 선방세포와 모세혈관에 손상을 주게 된다. 이에 따라 췌장에 허혈 상태가 유발되는데 이는 산성 환경을 조장하여 유리지방산의 독성을 강화하게 된 다. ${ }^{11-13}$ 여기에 chylomicron이 증가하면서 혈액의 점도가 증가 되고 췌장의 허혈은 더욱 심해지게 된다. 소포체 스트레스(en- doplasmic reticulum stress)도 HTG-AP의 병태생리학적 기전 으로 거론된다. ${ }^{14}$

\section{3. 임상 증상}

HTG-AP의 임상 증상은 다른 원인에 의한 급성 췌장염과 크 게 다르지 않다. ${ }^{715,16}$ 최근 발표된 체계적 문헌고찰에서 HTG$\mathrm{AP}$ 환자의 $65 \%$ 가 남성이었고 평균 나이는 42 세였다. 이 연구 에서 분석한 34 개의 논문 중 24 개에서 HTG-AP 환자의 성별을 확인할 수 있었는데 23 개 논문에서 남성이 여성보다 많은 것으 로 나타났다. ${ }^{3}$

한편 당뇨, 음주, 비만, 임신, 과거 췌장염 병력이나 고지혈증 의 과거력 및 가족력은 HTG-AP를 시사하는 임상 소견으로 알 려져 있다. ${ }^{16}$ 당뇨는 HTG-AP 환자에서 가장 흔하게 보는 2차 적 인자(secondary factor)이며 혈당 조절이 잘 되지 않는 당뇨 환자나 당뇨병성 케톤산증 환자에서는 혈중 중성지방 수치가 증가되는 것으로 보고되었다. ${ }^{17} \mathrm{HTG}-\mathrm{AP}$ 환자군에서 당뇨병 의 유병률은 일반 인구집단이나 췌장염이 없는 고중성지방혈 증 환자에 비해 횔씬 높은 것으로 알려져 있다. National Health and Nutrition Examination Survey 연구에 따르면 혈중 중성지 방이 정상인 미국 성인에서 당뇨병 유병률이 $5.2 \%$ 인데 반해, 고중성지방혈증(혈중 중성지방 $500-2,000 \mathrm{mg} / \mathrm{dL}$ ) 환자에서 당뇨병 유병률은 $14.6 \%$ 로 나타났고, ${ }^{18} \mathrm{HTG}-\mathrm{AP}$ 환자군 연구에 서 당뇨병 유병률은 $42.3-72 \%$ 로 보고되었다. ${ }^{6.9}$ 당뇨병에서 중 성지방의 증가는 인슐린 저항성과 연관된 것으로 보이며 이를 통해 과다한 유리지방산이 간으로 회수되고 very low density lipoprotein (VLDL) 생성이 증가되며 apolipoprotein B 합성이 감소되는 것으로 생각된다. 그리고 고인슐린혈증은 de novo 중성지방 합성을 촉진하는 것으로 알려져 있다. ${ }^{19}$

음주 또한 혈중 중성지방 수치를 높이는데 이는 중성지방 수 치가 정상인 사람에서도 나타나는 현상이다. 소량의 음주가 중 성지방 수치에 미치는 영향은 크지 않은데 비해, 만성적인 폭 음은 의미 있는 고중성지방혈증을 유발한다. 알코올은 간에서 large VLDL particle의 생성을 촉진하고, VLDL remnant 및 chylomicron으로부터 중성지방의 추출을 증가시킨다. 아울러 lipoprotein lipase (LPL) 활성도를 감소시키고 지방조직에서 지질생성(lipogenesis) 및 포도당 산화(glucose oxidation)를 줄 이는 것으로 알려져 있다. ${ }^{20}$

에스트로젠은 간에서 VLDL 생성을 촉진하여 고중성지방혈 증을 유발할 수 있다. ${ }^{21}$ 임산부에서 HTG-AP의 발생률이 증가 되는 것은 에스트로젠과 관련된 것으로 보이며 경구 피임약이 
나 tamoxifen도 고중성지방혈증을 유발할 수 있다. 이외에 clomiphene, propofol, valproic acid, mirtazapine, isotretinoin, protease inhibitor, beta-blocker 등이 고중성지방혈증을 일으 킬 수 있는 약제로 알려져 있다. ${ }^{3}$

그 동안 HTG-AP가 다른 원인에 의한 급성 췌장염에 비해 중증도가 더 높다는 주장이 계속 제기되었고 이에 관련된 연구 결과가 발표되었으나 아직 확실한 결론에 이르지는 못하였다. 한 체계적 문헌고찰에서 34 개의 HTG-AP 관련 논문을 분석하 였고 이 가운데 19 개의 논문에서 췌장염 중증도에 대한 평가가 있었는데, HTG-AP의 중증도를 다른 원인에 의한 췌장염의 중 증도와 비교한 논문은 9 개에 불과하였다. 이 중에 3 개의 연구 에서는 원인에 따른 중증도의 차이를 보이지 않은 반면 6 개의 연구에서는 HTG-AP가 다른 급성 췌장염에 비해 심한 중증도 를 보인다고 보고하였다. 하지만 포함된 연구에서 중증도를 측정하는 기준이 제각각이었고 case series 및 case control study가 포함된 반면 randomized controlled clinical trial은 하 나도 없는 등 현재까지의 연구 결과를 분석하는 것만으로는 결 론은 이끌어 내기 어려운 것으로 평가되었다. ${ }^{3}$ 이러한 의문에 대한 답을 얻기 위해서는 표준화된 중증도 측정 도구를 이용, 대규모의 연구가 이루어져야 할 것으로 보인다.

\section{4. 진단}

급성 췌장염 환자에서 혈중 중성지방 수치가 $1,000 \mathrm{mg} / \mathrm{dL}$ 이 상으로 증가된 경우 고중성지방혈증이 급성 췌장염의 원인일 가능성이 매우 높다. 그리고 중성지방 수치가 $500 \mathrm{mg} / \mathrm{dL}$ 이상 인 경우 HTG-AP를 의심해 볼 수 있는데 특히 급성 췌장염의 다른 원인이 불분명하거나 혈중 중성지방 측정이 지연된 경우 가능성이 더 높다. ${ }^{15}$ 혈중 중성지방은 복통 발생 시점부터 24 시 간 이내에 측정하는 것이 좋은데, 이는 금식 기간 동안 혈중 중 성지방 수치가 빠르게 감소하기 때문이다. 한 연구에 따르면 HTG-AP 환자의 대다수에서 72시간 금식 후 혈중 중성지방 수 치가 정상에 가깝게 감소되었고, 이 환자군 대부분에서 2 주 후 혈중 중성지방 수치는 정상보다 약간 높은 정도로 확인되었 다. ${ }^{22}$

혈중 중성지방 수치가 $500 \mathrm{mg} / \mathrm{dL}$ 를 넘는 경우 amylase 및 lipase 활성도 측정에 간섭을 일으켜 두 효소의 수치가 실제보다 낮게 측정될 수 있다. ${ }^{23-25}$ Fortson 등 ${ }^{6}$ 은 HTG-AP 환자에서 혈 중 amylase, lipase가 정상보다 두 배 이상 증가된 비율이 각각 $54 \%, 67 \%$ 에 불과하였다고 보고하였다. 따라서 진단시 amylase, lipase 결과 해석에 주의가 필요하다.

\section{5. 치료}

다른 급성 췌장염과 마찬가지로 금식, 수액 공급, 통증 조절 등이 기본적인 치료법이 된다. 이에 더하여 insulin, heparin, plasmapheresis 등이 HTG-AP의 치료에 효과적이라고 보고되 었다. 하지만 여러 연구 가운데 무작위 대조군 연구와 같은 강 력한 근거는 없는 실정이다.

\section{1) Insulin}

몇 가지 증례 보고에서 insulin 단독요법이 HTG-AP의 치료 에 효과적임이 보고되었다. ${ }^{26-28}$ Insulin은 LPL 활성도를 증가시 켜 chylomicron의 분해를 촉진하며 ${ }^{29,30}$ 동물지방 세포에서 LPL $\mathrm{mRNA}$ 를 증가시켜 합성을 촉진하는 것으로 나타났다. ${ }^{31}$ 아울 러 HTG-AP 환자의 상당수에서 조절되지 않는 당뇨병이 동반 되는데 insulin 투여를 통해 고혈당에 대한 치료 효과도 기대할 수 있다. 하지만 insulin의 효과는 당뇨병 환자에게만 국한되지 않으며 당뇨병을 동반하지 않은 고중성지방혈증의 치료에도 효과적임이 보고된 바 있다. ${ }^{26,27}$

심한 고중성지방혈증 치료시 insulin 피하주사는 흡수에 제 한이 있을 수 있으므로 정맥주사로 투여하는 것이 더 효과적일 가능성이 있으며 시간당 $0.1-0.3 \mathrm{U} / \mathrm{kg}$ 로 연속 정맥주입을 시작 하여 용량을 조절해 나가는 방법이 있다. ${ }^{16}$

\section{2) Heparin}

Heparin은 혈관 내피에서 LPL 분비를 촉진하며 ${ }^{32}$ 고중성지 방혈증 치료에 단독으로 33,34 혹은 insulin과 병합하여 사용되었 다. ${ }^{35,36}$ 하지만 heparin이 투여 초기에 혈중 LPL 농도를 증가시 키더라도 이는 곧장 파괴되기 때문에 장기간 사용할 경우 혈관 내피의 LPL이 고갈되고 chylomicron의 증가를 유발할 수 있다 는 것이 문제로 대두되었다. ${ }^{37,38}$ Watts 등 ${ }^{39}$ 은 heparin을 장기간 사용한 후 LPL 결핍이 생겨 HTG-AP가 발생한 임산부의 증례 를 보고하기도 하였다. 아울러 췌장 괴사가 동반된 환자에서는 heparin 사용시 출혈이 발생할 우려도 있다. ${ }^{40}$ 이에 최근에는 HTG-AP의 치료에서 heparin의 사용을 권장하지 않는 추세이 다. ${ }^{15}$

\section{3) Plasmapheresis}

Plasmapheresis는 혈중 chylomicron 및 VLDL로부터 중성지 방을 제거하고 췌장염을 유발하는 유리지방산의 생성을 막을 수 있다. 실제로 plasmapheresis의 효과를 보고한 논문을 보면 1 회 시행시 혈중 중성지방 농도가 $49-80 \%$ 감소되는 것으로 보 고되었다. ${ }^{7}$ 국내에서도 plasmapheresis를 통해 치료한 HTG- 
$\mathrm{AP}$ 증례가 보고되었고 모두 합병증 없이 호전되었다(Table 1). ${ }^{41,42}$ 하지만 무작위 대조군 연구가 이루어진 적은 없으며 plasmapheresis가 HTG-AP의 이환율(morbidity)과 사망률 (mortality)을 개선하는지도 아직 불확실하다. Chen 등 ${ }^{43}$ 은 해 당 기관에 plasmapheresis가 도입되기 전과 후로 나누어 HTG$\mathrm{AP}$ 환자의 임상 경과(clinical outcomes)를 분석하였다. 이 연 구에서 plasmapheresis는 증상 시작 시점부터 평균 3일째 시작 되었고 Ranson's score 3점이 넘는 심한 췌장염 환자에서 plasmapheresis군과 보존적 치료군 사이에 사망률, 합병증 차이는 보이지 않았다. 이 연구는 후향적 연구이며 단일 기관에서 이 뤄진 소규모 연구라는 한계가 있다. American Society for Apheresis의 가이드라인에서 HTG-AP는 category III 적응증에 해당하며 이는 HTG-AP에서 plasmapheresis의 적절한 역할이 확립되지 않았고 시행 여부를 상황에 따라 다르게 결정할 필요 가 있다는 것을 의미한다. ${ }^{44}$

Plasmapheresis는 고가의 치료이며 중심정맥관 삽입 및 일시 적인 항응고제 투여가 필요하므로 균혈증이나 혈전증, 출혈의 위험성을 내포한다. 따라서 무조건적으로 시행하기보다는 상 황에 맞게 적용할 필요가 있으며 표준 치료로 인정받기 위해서 무작위 임상 시험이 필요하다고 생각된다. 아울러 plasmapheresis의 시작 시점이나 어떤 항응고제를 투여할 것인지, 수 액 보충(fluid replacement)을 위해 신선동결혈장과 알부민 중 어떤 것을 사용하는 것이 좋을지 등 구체적인 시행 방법에 대 한 표준화도 필요하다. ${ }^{16}$

\section{4) 재발의 예방}

HTG-AP의 재발을 막기 위해서는 다면적 접근이 필요하다. 체중 감소, 지방이나 단순당 섭취 제한, 금주와 같은 생활습관 개선(lifestyle modification), 당뇨병과 같은 위험인자의 조절, 고중성지방혈증을 유발할 수 있는 약물의 중단이 기본적인 조 치가 된다. ${ }^{15}$
지질 강하제(lipid lowering agent)도 도움이 되며 HTG-AP 환자에서 투여에 문제가 없다면 처방을 시작해야 한다. ${ }^{16} \mathrm{Fi}-$ brate가 고중성지방혈증 치료에 1 차 치료제로 추천되는데, 중 성지방의 이화작용을 촉진하며 VLDL 분비를 낮추는 작용을 하는 것으로 알려져 있고, ${ }^{45}$ 혈중 중성지방을 $40-60 \%$ 낮추고 high density lipoprotein 콜레스테롤 수치를 높이는 효과가 있 다. ${ }^{15}$ Fibrate는 대체로 복용하는데 큰 문제가 없으나 statin과 병용할 경우 근육병증이나 횡문근융해증의 위험도를 조금 증 가시키는 것으로 되어 있어 주의해야 한다. 이러한 위험도는 gemfibrozil 같은 기존의 fibrate에서 저명하며 fenofibric acid 같은 새로운 fibrate 유도체에서는 횔씬 적은 것으로 알려져 있 다. ${ }^{46}$ Statin은 중성지방을 낮추는 효과가 적어서 고중성지방혈 증 치료에 단독요법으로는 추천되지 않는다. 하지만 fibrate와 병합 시 상승 효과를 보이므로 fibrate 단독요법으로 조절되지 않는 심한 고중성지방혈증 치료시 statin 병용을 고려해야 한 다. ${ }^{47}$

Nicotinic acid (niacin)는 fibrate보다 효과가 약해 2차 치료 제로 고려하여 볼 수 있으나 안면홍조, 소화기계 불편감, 간 독 성 등 부작용에 의해 사용이 제한된다. ${ }^{15,16}$ 오메가-3 지방산은 임상 시험에서 $500-2,000 \mathrm{mg} / \mathrm{dL}$ 의 중성지방혈증을 $45 \%$ 낮추 는 것으로 보고되었다. ${ }^{4}$ 다른 약제와 병용 투여하는 것이 추천 된다. ${ }^{49}$

2013년에 급성 췌장염 병력이 있고 LPL 결핍 및 심각한 고중 성지방혈증을 동반한 환자에게 alipogenic tiparvovec (AAV1$\mathrm{LPL}_{\text {s477x }}$ ) 유전자 치료 시행시 중성지방 수치 및 췌장염 감소에 효과가 있다는 소규모 연구 결과가 발표되었다. ${ }^{50}$ 2016년에는 19 명의 환자를 대상으로 장기 후향적 분석결과가 발표되었는 데 췌장염과 복통 발생이 대략 $50 \%$ 감소되었고 중증 급성 췌 장염(severe acute pancreatitis)은 한 건도 발생하지 않은 것으 로 나타났다. ${ }^{51}$

Table 1. HTG-AP cases managed with plasmapheresis in Korea

\begin{tabular}{lccccccc}
\hline Author & Gender & Age & Comorbidities & Alcohol & $\begin{array}{c}\text { Serum TG level } \\
\mathbf{( m g / d L})\end{array}$ & $\begin{array}{c}\text { Severity* } \\
\text { plasmapheresis }\end{array}$ \\
\hline Bae et al. $^{41}$ & Male & 36 & None & Yes & 7,720 & Moderate & 4th day \\
Bae et al. $^{41}$ & Male & 35 & None & Yes & 3,355 & Moderate & 3rd day \\
Lee et al. ${ }^{42}$ & Female & 29 & $\begin{array}{c}\text { Dyslipidemia, } \\
\text { Pregnancy }\end{array}$ & No & 4,963 & Moderate & 3 3rd day \\
\hline
\end{tabular}

*The revised Atlanta classification (2013). 
Table 2. HTG-AP cases developed in pregnancy in Korea

\begin{tabular}{|c|c|c|c|c|c|c|}
\hline Author & Age & $\begin{array}{l}\text { Gestational age } \\
\text { (weeks) }\end{array}$ & Comorbidities & $\begin{array}{l}\text { Serum TG level } \\
\qquad(\mathrm{mg} / \mathrm{dL})\end{array}$ & Treatment & $\begin{array}{c}\text { Outcome } \\
\text { (gestational age, weeks) }\end{array}$ \\
\hline Choi et al. ${ }^{55}$ & 31 & 32 & none & 2,295 & Supportive care & Preterm birth (33) \\
\hline Kang et al. ${ }^{56}$ & 36 & 14 & none & 5,960 & $\begin{array}{l}\text { Insulin+glucose, omega 3, } \\
\text { fenofibrate }\end{array}$ & Discharge without sequelae \\
\hline Kim et al. ${ }^{57}$ & 26 & 26 & Gestational diabetes & 3,200 & $\begin{array}{l}\text { Insulin, heparin, } \\
\text { lipid lowering agent after } \\
\text { delivery }\end{array}$ & $\begin{array}{l}\text { Emergent CS and } \\
\text { preterm birth (26), } \\
\text { perinatal death }\end{array}$ \\
\hline Lee et al. ${ }^{42}$ & 29 & 20 & Dyslipidemia & 4,963 & $\begin{array}{l}\text { Insulin, heparin, } \\
\text { plasmapheresis }\end{array}$ & Discharge without sequelae \\
\hline Chung et al..$^{58}$ & 36 & 32 & Gestational diabetes & 1,996 & Insulin & Full term birth $(\mathrm{CS}, 38)$ \\
\hline Jeon et al. ${ }^{59}$ & 28 & 22 & none & 10,392 & Insulin & $\begin{array}{l}\text { Intrauterine fetal and } \\
\text { maternal death (22) }\end{array}$ \\
\hline
\end{tabular}

CS, cesarean section; TG : triglyceride.

혈중 중성지방 농도는 가급적 정상에 가깝게 낮추는 것이 바 람직하다. 데이터베이스를 이용한 한 연구에서 평균 혈중 중성 지방을 $500 \mathrm{mg} / \mathrm{dL}$ 미만으로 낮추지 못하는 경우 췌장염의 가 능성이 유의하게 높음을 보고하였다(hazard ratio $1.79,95 \% \mathrm{CI}$ $1.47-2.18){ }^{52} 2$ 년 뒤 같은 저자들은 혈중 중성지방이 $500 \mathrm{mg} / \mathrm{dL}$ 이상인 환자에서 중성지방 수치를 $200 \mathrm{mg} / \mathrm{dL}$ 미만으로 낮출 경우 그렇지 못한 경우보다 급성 췌장염의 빈도를 100 인년 (person-year) 당 1.1회에서 0.4회로 낮춤을 보고하였다(adjusted incidence rate ratio, $0.45 ; 95 \% \mathrm{CI}, 0.34-0.60){ }^{53}$

\section{6. 임신 중 발생한 HTG-AP}

앞에서 언급한 것처럼 HTG-AP는 임신 중 발생하는 췌장염 의 절반 이상을 차지하며 한 기관의 발표에 따르면 15 년간 6,790 건의 임신 중 1 건이 발생한 것으로 보고되었다. ${ }^{4}$ 임신 중 발생하는 고중성지방혈증은 대개 가족성 고중성지방혈증이지 만 비가족성인 경우도 보고되고 있다. ${ }^{54}$ 임신 중 발생한 HTG$\mathrm{AP}$ 의 치료에 대해 여러 증례 보고가 있었는데 plasmapheresis, insulin, heparin, 식이 요법, gemfibrozil 투여 등 다양한 치료가 이루어졌다. ${ }^{16}$

국내에서도 임신 중 발생한 HTG-AP 증례가 보고되었고 KoreaMed에서 검색시 6건의 증례가 확인되었다. ${ }^{42,55-59}$ 해외 증 례와 마찬가지로 plasmapheresis, insulin, heparin, fibric acid 투여 등 다양한 치료가 이루어졌고 잘 회복된 경우도 있었으나 산모나 신생아가 사망한 증례도 보고되었다. Table 2에 국내의 증례보고를 정리하였다.

\section{결 론}

고중성지방혈증은 급성 췌장염의 원인으로 인정받고 있으 며 전체 급성 췌장염의 $9 \%$ 정도가 고중성지방혈증에 의한 것 으로 보고되었다. 따라서 급성 췌장염 환자를 진단하면 혈중 중성지방 수치를 항상 측정하여야 하며 정확한 진단을 위해 가 능한 빠른 시점에 측정하는 것이 중요하다. 이를 통해 HTG$\mathrm{AP}$ 에 특화된 진료를 시행할 수 있다. 아울러 아직까지 HTG$\mathrm{AP}$ 치료에 관한 무작위 대조군 임상 시험이 없는데 관련 연구 가 이뤄져야 하며 현재 널리 인정받는 가이드라인이 없으므로 이를 해결하기 위한 국제적인 노력도 필요하다.

\section{요 약}

고중성지방혈증은 급성 췌장염의 원인으로 인정받고 있으 며 전체 급성 췌장염의 $9 \%$ 정도가 고중성지방혈증에 의한 것 으로 보고되었다. HTG-AP의 임상 증상은 다른 원인에 의한 급성 췌장염과 크게 다르지 않은 것으로 알려져 있고 중증도 (severity)가 더 심한지는 아직 확실하지 않다. 급성 췌장염 환 자에서 혈중 중성지방 수치가 $1,000 \mathrm{mg} / \mathrm{dL}$ 이상으로 증가된 경우 HTG-AP 가능성이 매우 높고, 중성지방 수치가 $500 \mathrm{mg} /$ $\mathrm{dL}$ 이상인 경우 HTG-AP를 의심해 볼 수 있다. 당뇨, 음주, 비 만, 임신, 고지혈증의 과거력 및 가족력은 HTG-AP를 시사하 는 임상 소견으로 알려져 있다. 기본적인 치료는 다른 췌장염 과 크게 다르지 않고 이에 더해 insulin 및 plasmapheresis가 효 
과적이라고 보고되었으나 무작위 대조군 연구가 아직 없는 실 정이다. 재발의 예방을 위해 생활습관 개선 및 fibrate 같은 지 질 강하제의 투여가 필요하다.

국문 색인: 고중성지방혈증, 급성 췌장염, 인슐린, 혈장분리 교환술

\section{Conflicts of Interest}

The author has no conflicts to disclose.

\section{REFERENCES}

1. Whitcomb DC. Clinical practice. Acute pancreatitis. N Engl J Med 2006;354:2142-2150.

2. Yadav $D$, Lowenfels $A B$. Trends in the epidemiology of the first attack of acute pancreatitis: a systematic review. Pancreas 2006;33:323-330.

3. Carr RA, Rejowski BJ, Cote GA, Pitt HA, Zyromski NJ. Systematic review of hypertriglyceridemia-induced acute pancreatitis: a more virulent etiology? Pancreatology 2016;16:469-476.

4. Chang CC, Hsieh YY, Tsai HD, Yang TC, Yeh LS, Hsu TY. Acute pancreatitis in pregnancy. Zhonghua Yi Xue Za Zhi (Taipei) 1998;61:85-92.

5. Toskes PP. Hyperlipidemic pancreatitis. Gastroenterol Clin North Am 1990;19:783-791.

6. Fortson MR, Freedman SN, Webster PD 3rd. Clinical assessment of hyperlipidemic pancreatitis. Am J Gastroenterol 1995;90:2134-2139.

7. Valdivielso P, Ramírez-Bueno A, Ewald N. Current knowledge of hypertriglyceridemic pancreatitis. Eur J Intern Med 2014;25:689-694.

8. Sandhu S, Al-Sarraf A, Taraboanta C, Frohlich J, Francis GA. Incidence of pancreatitis, secondary causes, and treatment of patients referred to a specialty lipid clinic with severe hypertriglyceridemia: a retrospective cohort study. Lipids Health Dis 2011;10:157.

9. Lloret Linares C, Pelletier AL, Czernichow S, et al. Acute pancreatitis in a cohort of 129 patients referred for severe hypertriglyceridemia. Pancreas 2008;37:13-2.

10. Bessembinders K, Wielders J, van de Wiel A. Severe hypertriglyceridemia influenced by alcohol (SHIBA). Alcohol Alcohol 2011;46:113-116.

11. Havel RJ. Pathogenesis, differentiation and management of hypertriglyceridemia. Adv Intern Med 1969;15:117-154.

12. Saharia P, Margolis S, Zuidema GD, Cameron JL. Acute pancreatitis with hyperlipemia: studies with an isolated perfused canine pancreas. Surgery 1977;82:60-67.

13. Kimura W, Mössner J. Role of hypertriglyceridemia in the pathogenesis of experimental acute pancreatitis in rats. Int J Pancreatol 1996;20:177184.

14. Zeng $Y$, Wang $X$, Zhang W, Wu K, Ma J. Hypertriglyceridemia aggravates ER stress and pathogenesis of acute pancreatitis. Hepatogastro- enterology 2012;59:2318-2326.

15. Scherer J, Singh VP, Pitchumoni CS, Yadav D. Issues in hypertriglyceridemic pancreatitis: an update. J Clin Gastroenterol 2014;48:195-203.

16. Tsuang W, Navaneethan U, Ruiz L, Palascak JB, Gelrud A. Hypertriglyceridemic pancreatitis: presentation and management. Am J Gastroenterol 2009;104:984-991.

17. Nair S, Yadav D, Pitchumoni CS. Association of diabetic ketoacidosis and acute pancreatitis: observations in 100 consecutive episodes of DKA. Am J Gastroenterol 2000;95:2795-2800.

18. Christian JB, Bourgeois N, Snipes R, Lowe KA. Prevalence of severe ( 500 to $2,000 \mathrm{mg} / \mathrm{dl}$ ) hypertriglyceridemia in United States adults. Am J Cardiol 2011;107:891-897.

19. Subramanian $S$, Chait A. Hypertriglyceridemia secondary to obesity and diabetes. Biochim Biophys Acta 2012;1821:819-825.

20. Van de Wiel A. The effect of alcohol on postprandial and fasting triglycerides. Int J Vasc Med 2012;2012:862504.

21. Berglund L, Brunzell JD, Goldberg AC, et al. Evaluation and treatment of hypertriglyceridemia: an Endocrine Society clinical practice guideline. J Clin Endocrinol Metab 2012;97:2969-2989.

22. Dominguez-Muñoz JE, Malfertheiner P, Ditschuneit HH, et al. Hyperlipidemia in acute pancreatitis. Relationship with etiology, onset, and severity of the disease. Int J Pancreatol 1991;10:261-267.

23. Lesser PB, Warshaw AL. Diagnosis of pancreatitis masked by hyperlipemia. Ann Intern Med 1975;82:795-798.

24. Warshaw AL, Bellini CA, Lesser PB. Inhibition of serum and urine amylase activity in pancreatitis with hyperlipemia. Ann Surg 1975;182:7275.

25. Fallat RW, Vester JW, Glueck CJ. Suppression of amylase activity by hypertriglyceridemia. JAMA 1973;225:1331-1334.

26. Jabbar MA, Zuhri-Yafi MI, Larrea J. Insulin therapy for a non-diabetic patient with severe hypertriglyceridemia. J Am Coll Nutr 1998;17:458461.

27. Mikhail N, Trivedi K, Page C, Wali S, Cope D. Treatment of severe hypertriglyceridemia in nondiabetic patients with insulin. Am J Emerg Med 2005;23:415-417.

28. Tamez-Perez HE, Saenz-Gallegos R, Hernandez-Rodriguez K, et al. Insulin therapy in patients with severe hypertriglyceridemia. Rev Med Inst Mex Seguro Soc 2006;44:235-237.

29. Eckel RH. Lipoprotein lipase. A multifunctional enzyme relevant to common metabolic diseases. N Engl J Med 1989;320:1060-1068.

30. Goldberg IJ. Lipoprotein lipase and lipolysis: central roles in lipoprotein metabolism and atherogenesis. J Lipid Res 1996;37:693-707.

31. Ong JM, Kirchgessner TG, Schotz MC, Kern PA. Insulin increases the synthetic rate and messenger RNA level of lipoprotein lipase in isolated rat adipocytes. J Biol Chem 1988;263:12933-12938.

32. Korn ED. Clearing factor, a heparin-activated lipoprotein lipase. I. Isolation and characterization of the enzyme from normal rat heart. J Biol Chem 1955;215:1-14.

33. Sharma P, Lim S, James D, Orchard RT, Horne M, Seymour CA. Pancre- 
atitis may occur with a normal amylase concentration in hypertriglyceridaemia. BMJ 1996;313:1265.

34. Loo CC, Tan JY. Decreasing the plasma triglyceride level in hypertriglyceridemia-induced pancreatitis in pregnancy: a case report. Am J Obstet Gynecol 2002;187:241-242.

35. Alagözlü $H$, Cindoruk M, Karakan T, Unal S. Heparin and insulin in the treatment of hypertriglyceridemia-induced severe acute pancreatitis. Dig Dis Sci 2006;51:931-933.

36. Jain P, Rai RR, Udawat $H$, Nijhawan S, Mathur A. Insulin and heparin in treatment of hypertriglyceridemia-induced pancreatitis. World J Gastroenterol 2007;13:2642-2643.

37. Näsström B, Olivecrona G, Olivecrona T, Stegmayr BG. Lipoprotein lipase during continuous heparin infusion: tissue stores become partially depleted. J Lab Clin Med 2001;138:206-213.

38. Nasstrom B, Stegmayr BG, Olivecrona G, Olivecrona T. Lower plasma levels of lipoprotein lipase after infusion of low molecular weight heparin than after administration of conventional heparin indicate more rapid catabolism of the enzyme. J Lab Clin Med 2003;142:90-99.

39. Watts GF, Cameron J, Henderson A, Richmond W. Lipoprotein lipase deficiency due to long-term heparinization presenting as severe hypertriglyceridaemia in pregnancy. Postgrad Med J 1991;67:1062-1064.

40. Anderson F, Mbatha SZ, Thomson SR. The early management of pancreatitis associated with hypertriglyceridaemia. S Afr J Surg 2011;49:8284.

41. Bae JH, Baek SH, Choi HS, et al. Acute pancreatitis due to hypertriglyceridemia: report of 2 cases. Korean J Gastroenterol 2005;46:475-480.

42. Lee YJ, Park DS, Kim TH, Cho JH. A case of hypertriglyceridemia induced gestational pancreatitis treated by plasma exchange. Korean J Blood Transfus 2011;22:70-75.

43. Chen JH, Yeh JH, Lai HW, Liao CS. Therapeutic plasma exchange in patients with hyperlipidemic pancreatitis. World J Gastroenterol 2004;10:2272-2274.

44. Schwartz J, Winters JL, Padmanabhan A, et al. Guidelines on the use of therapeutic apheresis in clinical practice-evidence-based approach from the Writing Committee of the American Society for Apheresis: the sixth special issue. J Clin Apher 2013;28:145-284.

45. Staels B, Dallongeville J, Auwerx J, Schoonjans K, Leitersdorf E, Fruchart JC. Mechanism of action of fibrates on lipid and lipoprotein metabolism. Circulation 1998;98:2088-2093.

46. Schima SM, Maciejewski SR, Hilleman DE, Williams MA, Mohiuddin $\mathrm{SM}$. Fibrate therapy in the management of dyslipidemias, alone and in combination with statins: role of delayed-release fenofibric acid. Expert Opin Pharmacother 2010;11:731-738.
47. Expert Panel on Detection, Evaluation, and Treatment of High Blood Cholesterol in Adults. Executive summary of the third report of The National Cholesterol Education Program (NCEP) expert panel on detection, evaluation, and treatment of high blood cholesterol In adults (adult treatment panel III). JAMA 2001;285:2486-2497.

48. Harris WS, Ginsberg HN, Arunakul N, et al. Safety and efficacy of Omacor in severe hypertriglyceridemia. J Cardiovasc Risk 1997;4:385-391.

49. Hooper L, Thompson RL, Harrison RA, et al. Risks and benefits of omega 3 fats for mortality, cardiovascular disease, and cancer: systematic review. BMJ 2006;332:752-760.

50. Gaudet D, Méthot J, Déry S, et al. Efficacy and long-term safety of alipogene tiparvovec (AAV1-LPLS447X) gene therapy for lipoprotein lipase deficiency: an open-label trial. Gene Ther 2013;20:361-369.

51. Gaudet D, Stroes ES, Methot J, et al. Long-term retrospective analysis of gene therapy with alipogene tiparvovec and its effect on lipoprotein lipase deficiency-induced pancreatitis. Hum Gene Ther 2016;27:916925.

52. Christian JB, Arondekar B, Buysman EK, Johnson SL, Seeger JD, Jacobson TA. Clinical and economic benefits observed when followup triglyceride levels are less than $500 \mathrm{mg} / \mathrm{dL}$ in patients with severe hypertriglyceridemia. J Clin Lipidol 2012;6:450-461.

53. Christian JB, Arondekar B, Buysman EK, Jacobson TA, Snipes RG, Horwitz RI. Determining triglyceride reductions needed for clinical impact in severe hypertriglyceridemia. Am J Med 2014;127:36-44.e1.

54. Eskandar O, Eckford S, Roberts TL. Severe, gestational, non-familial, non-genetic hypertriglyceridemia. J Obstet Gynaecol Res 2007;33:186189.

55. Choi HS, Park JH, Kim JY, Im MW, Lee BI, Lee WY. Hypertriglyceridemia induced acute pancreatitis in pregnancy. Korean J Obst Gynecol 2008;51:1514-1518.

56. Kang JY, Choi GY, Jeong HS, et al. Hypertriglyceridemia-induced acute pancreatitis in pregnancy: a case report. Korean J Med 2009;77:104108.

57. Kim GH, Jun HA, Song JE, Lee KY, Kim SS. A case of acute pancreatitis induced by hypertriglyceridemia in gestational diabetes. Korean J Obstet Gynecol 2010;53:535-539.

58. Chung HH, Park SH, Yoon JS, Won KC, Lee HW. Ketoacidosis with hypertriglyceridemia-induced pancreatitis in a patient with gestational diabetes: a case report. Endocrinol Metab 2012;27:89-92.

59. Jeon HR, Kim SY, Cho YJ, Chon SJ. Hypertriglyceridemia-induced acute pancreatitis in pregnancy causing maternal death. Obstet Gynecol Sci 2016;59:148-151. 